\title{
Students' Perceptions on the Use of E-Portfolio for Learning Assessment
}

\author{
Chalim Fathul Muin 1 , Hafidah 2
}

DOI: 10.35445/alishlah.v13i1. 485

\begin{abstract}
Article Info
Abstract

Keywords:

E-portfolio Assessment

Qualitative research

Students' perception

This study aims at probing students' perceptions of utilizing e-portfolio for learning at the university. The study was qualitatively conducted as a case study. The subjects were 16 undergraduate students of the seventh semester in a university. The data were obtained by conducting interviews and disseminating a questionnaire. The results of the study revealed that most participants demonstrated positive views towards the use of e-portfolio. Further, the participants acknowledged some crucial benefits of utilizing the e-portfolio. They were extended to; increasing the motivational beliefs and self-efficacy, learning new things, accomplishing the English tasks effectively, giving beneficial effects for the learning, and improving students' ability in English. The findings are expected to bring light to stakeholders to consider e-portfolio to encourage students' learning enthusiasm and engagement.
\end{abstract}

Kata kunci:

Penilaian e-portfolio

Peneltian kualitatif

Persepsi siswa

\begin{abstract}
Abstrak
Penelitian ini bertujuan untuk mengetahui persepsi mahasiswa dalam menggunakan e-portfolio untuk pembelajaran di perguruan tinggi. Studi ini adalah studi kasus yang dilakukan secara kualitatif. Subjek penelitiannya 16 mahasiswa program sarjana semester tujuh di sebuah universitas. Pengumpulan data dilakukan dengan wawancara dan kuesioner. Hasil penelitian mengungkapkan bahwa sebagian besar partisipan memberikan pandangan positif terhadap penggunaan e-portfolio. Selanjutnya, para peserta mengakui beberapa manfaat dari penggunaan e-portfolio. Mereka berpendapat bahwa; e-portofolio dapat meningkatkan keyakinan, motivasi dan self-efficacy, mempelajari hal-hal baru, menyelesaikan tugas-tugas bahasa Inggris secara efektif, memberikan efek yang bermanfaat bagi pembelajaran, dan meningkatkan kemampuan bahasa Inggris siswa. Hasil ini diharapkan dapat memberikan pemahaman kepada para pemangku kepentingan untuk mempertimbangkan penggunaan e-portfolio untuk mendorong antusiasme dan keterlibatan belajar siswa.
\end{abstract}

\section{INTRODUCTION}

The portfolio has been widely used as one of the alternative assessments in language learning. A portfolio is a students' collected work to monitor the students' improvement in a certain period. In addition, Weigle (2007) considered a portfolio as a series of students' work indicating both students' progress and achievement. A portfolio facilitates the students to observe their learning development

\footnotetext{
${ }^{1}$ UIN Raden Mas Said Surakarta, Sukoharjo, Indonesia

Email: chalimfathul10@gmail.com

2 UIN Raden Mas Said Surakarta, Sukoharjo, Indonesia

Email: hafidah_hua@yahoo.com
} 
to take action regarding their learning. As the demand for implementing the technology for teaching and learning activities increases, there is a shift from the portfolio into an e-portfolio (electronic portfolio). Barrett (2007) certified that an e-portfolio assists teachers in managing students' work into various formats by engaging the integration of electronic technology. The integrated portfolio with information and communication technology allows teachers to access the students' work more efficiently.

A portfolio becomes an effective assessment tool to assess the students' work. Like the paperbased portfolio, an e-portfolio gives advantages in assessing language skills. It helps to develop students' writing performance, develop teachers' roles, support learning, encourage students' participation, enhance the testing process, improve students' autonomous learning, and maintain lifetime learning (Barrot, 2014, 2015; Cheng, 2008). Regarding its objectives, this study focuses on the use of e-portfolio at the university level since portfolio has been mainly applied for language assessment.

In the context of higher education, generally, teachers or lecturers have been utilizing eportfolio. Several previous studies about the implementation of e-portfolio reveal that e-portfolio is beneficial for the teaching and learning process. Research conducted by Barrot (2016) exhibited that e-portfolio allowed students to reflect upon their learning, check the learning progress, and motivates students in learning. Also, Hung (2012) attained that e-portfolio created a positive washback. Moreover, it facilitates learners to conduct peer feedback, support learners' professional development, and develop learners' critical thinking. Hung (2012), however, affirmed that eportfolio could also initiate negative wash-back, such as anxiety to have more viewers pertinent to ICT, writing, and students' autonomous learning (Thang et al., 2012). Furthermore, Cheng \& Chau (2013) conveyed that self-regulated learning strategies play an important role in the students' eportfolio achievement.

Although there have been many studies revealing the benefits of integrating the e-portfolio for students' assessment, little has been known about how students view the use of e-portfolio for assessment. Therefore, to fill this gap, this study explored the students' viewpoints towards the use of e-portfolio assessment in university.

A portfolio is one of the alternative assessments in language teaching. According to Genesee \& Upshur (1996), the portfolio is students' collected artefacts produced to show students' attempts, progress, and attainment in a certain subject. Goldsmith (2007) expressed that the students and educational institutions can take some advantages of e-portfolio since it helps them figure out their success in teaching them. Furthermore, it helps them review students' learning experiences and accomplishments and students' individual goals. The students can learn to be responsible for their learning to evaluate themselves and reflect on the learning. Hence, students become more accountable and motivated in learning (Akçll \& Arap, 2009).

Since the portfolio has various advantages for assessment and learning, it is now implemented in primary to a higher level of education such as at the university. Nowadays, due to the rapid development of information and communication technology in language teaching, the portfolio has been being integrated into technology in its implementation. In short, instead of using paper, the electronic portfolio is considered more efficient.

Lorenzo \& Ittelson (2005) defined an e-portfolio as a personalized web-based work collection, responses to work, and reflections that can be used to authenticate key skills and achievements for various contexts and periods. It is generally administered and conducted on websites, emails, and other kinds of social media. Some researches revealed that an e-portfolio tends to be the proper choice (Baturay \& Daloğlu, 2010; Chye et al., 2013; Meyer et al., 2010). This fact is due to the benefit of e-portfolio; (1) presenting a motivated learning situation by the audiovisual, (2) facilitating students as well as the teachers to create a portfolio in diverse format, (3) maintaining practicality and low priced since it is not restrained by time and place, (4) matching to the learners' current learning style, and (5) providing free access to other learners drawing more audience. Knowing this bunch of benefits, teachers and institutions, accordingly, put more concern about the use of the eportfolio.

Google Classroom is a platform developed by Google for an academic purpose that is blended learning. It is a user-friendly application that does not take an excessive number of spaces on a 
smartphone's depository. Furthermore, it can help educators and students keeping on the lesson's track. It allows users to create a virtual class that functions as a conventional class. However, it requires additional time, cash, and space.

Also, such an application enables educators to spend more time with their students while wasting less time on desk work. With the newest development, some new functions were inserted into Google Classroom. The new feature allows more than one teacher to set a schedule for advanced classes (Iftakhar, 2016). Additionally, Janzen (2014) pointed out that such an app was intentionally designed to simplify instructions for disclosing and the following assignment. Also, it facilitates communication through announcements, emails, and pop-up messages.

\section{METHODS}

The study was qualitatively conducted as a case study to scrutinize an in-depth detail of the issue based on the real circumstance (Creswell \& Creswell, 2017). The elemental consideration in employing the qualitative method is because the study attempted to disclose the particularities instead of merely summarizing narrow views. Also, the study used a case study to enable the researchers to develop an in-depth analysis of the issue (Stake, 1995; Yin, 2017).

A population is a group of people representing similar characteristics. For instance, all educators would compose the population of educators, and all secondary school directors in a school region would comprise the population of directors. Therefore, a population can be small or large. You have to choose what group you might want to think about (Creswell \& Poth, 2016). Concerning the purpose of the study, the study population was the students of the English Education Department in the seventh semester of the university.

The sample is known as the representation of the population in research. Creswell \& Creswell (2017) expressed that a sample is a subgroup of the chosen population that the specialist researcher intends to examine to make speculations. In an ideal circumstance, the researcher can choose a sample of people depicting the whole population. To begin with, purposive sampling is applied. In short, purposive sampling can be defined as purposively picking a specific sample based on the requirements (properties, traits, characteristics, and criteria). The researcher, for the study, picked the students from one class. There were four classes at that university. A total of 16 students completed the questionnaire. However, only three students were involved in the interview session.

The study data were obtained from both interviews and questionnaires (Phellas et al., 2011). A questionnaire was disseminated to students to discover their perceptions of e-portfolio in the teaching and learning process. Moreover, the data obtained from the interview were used to intensify the data obtained from the questionnaire. The questionnaire data were analyzed and investigated by utilizing a few stages to characterize and depict whether or not the students agree in using e-portfolio for their learning. Besides, the interview session was recorded to assist the researchers in the data transcription. The interview data were used to strengthen the information acquired from the questionnaire.

\section{FINDINGS AND DISCUSSION}

This section elaborates the encountered findings pertinent to the study focus. The details are interpreted to elaborate the proportion of students' perception of e-portfolio for undergraduate students. The majority of students indicated an identical belief that the integration of the e-Portfolio did affect their motivational beliefs of learning English. A participant indicated that she got valuable or enjoyable experiences from the e-portfolio. This section elaborates the encountered finding and discussion pertinent to the study focus. The details are interpreted to elaborate the proportion of students' perception of E-portfolio for undergraduate students. The majority of students indicated an identical belief that the integration of the e-Portfolio did affect their motivational beliefs of learning English. A participant stated that she got valuable or enjoyable experiences from the eportfolio. Of the 16 respondents, 70\% responded that they were happy in completing their 
assignments from the lecturers. In contrast, $30 \%$ of the subjects demonstrated their disagreement regarding the utilization of e-portfolio. This study has the same result, which stated that students could improve their learning styles (Yastibas \& Yastibas, 2015).

Furthermore, more than three-fourths $(88 \%)$ of the subjects confessed that they enjoyed learning new things from the assignment. They were given the experience to explain to their classmates. Fourteen participants postulated that they would get a better achievement if learning by using an e-portfolio. In addition, only two students were still hesitant to get a good mark. This finding is affirmed by Brown et al. (2009), asserting that cooperative learning with the assessment method can assist students to achieve better results. Also, the participants believed that making use of an eportfolio for learning significantly affected their self-efficacy. Respondents were asked if they could follow the lecture well. Three-fourths $(75 \%)$ of them responded that they felt glad and could follow the lecture. With this regard, four participants contradicted that they could hardly understand the course. They expressed their discomfort due to an unstable internet connection. Two students even reported that they got into trouble with the online submission due to internet disruption. Compared with the others, nine students admitted that they could understand the lectures comprehensively. Of those who indicated that e-portfolio assessment affected their self-confidence levels, $81 \%$ thought it helped them solve the assignment or the task. However, $19 \%$ answered that they did not feel engaged with such challenges.

Regarding the participants' level of test anxiety, 50\% of the participants responded that they were confused and worried about answering the questions. In other words, they acknowledged that the instructions were not delivered. Almost all participants (99\%) disclosed that they thought they had difficulties answering the queries during the test. This validated that imperfections or mistakes can adversely induce their actual identity (Back et al., 2010). However, five students were confident and positively thought they could solve the questions. Finally, eleven students were upset about the queries since they could not provide the demanded answers. Uniquely, five students affirmed that they could still be happy even though they could not answer the questions. Commonly, most of the students demonstrated positive perceptions related to the integration of e-portfolio for their learning. Most students considered that e-portfolio has good effects on their learning achievement. In addition, the students confessed that the e-portfolio is user-friendly. Besides, the students found that an e-portfolio is helpful to improve their ability to learn English. These findings are in line with Barrot (2015) and Karami et al. (2019), elaborating that a portfolio helps the students to develop their performance in writing, develop the teachers' roles, support learning, encourage students' participation, enhance the testing process, improve students' autonomous learning, and maintain lifetime learning.

The students thought that the e-portfolio has positive effects on students' English learning. The study revealed that $88 \%$ of the participants agreed that an e-portfolio is effective in learning English. Meanwhile, only $12 \%$ of the participants disagreed with the effectiveness of the e-portfolio to facilitate them in learning English. Furthermore, about the role of the e-portfolio to assist the completion of the task, $81 \%$ of the participants demonstrated positive responses while $19 \%$ of them displayed their disagreement. These percentages indicate that most students admitted that the eportfolio is beneficial to use in learning English. This finding is in line with the previous study conducted by Hung (2012), revealing that e-portfolio constructed positive wash-back. This study also revealed students' positive attitude towards the use of e-portfolio in learning English. The percentage shows that $69 \%$ of the participants felt that e-portfolio increases their English ability. Meanwhile, $31 \%$ of the participants did not share similar views. In addition, with the same proportion, $69 \%$ of the participants are keen to use the e-portfolio to learn English and for other purposes. These findings are also in line with Barrot (2015) about the benefit of e-portfolio in that it develops students' performance and supports the students' learning.

In addition, the students' felt that e-portfolio is easy to manage. The study findings showed that $81 \%$ of the participants agreed that an e-portfolio is easy in terms of usage. They were able to 
use it independently after the first instructions. On the other hand, $19 \%$ of the participants considered that Google classroom was not user-friendly. Moreover, $94 \%$ of the participants thought they were familiar with e-portfolio since they first used the e-portfolio. $88 \%$ of the students accepted that it was an easy-to-memorize learning platform, while $12 \%$ had difficulty recognizing it. Thus, the findings imply that most of the students considered e-portfolio a simple platform.

To sum up, these results signal the advantages of e-portfolio in maintaining practicality and matching the learners' current learning style. Besides, concerning the learning task of the e-portfolio, the students found that e-portfolio is helpful to improve their ability in learning English. $75 \%$ of the participants perceived that the e-portfolio-based task enhanced their interest in learning English. In comparison, $25 \%$ of them postulated different perceptions. Moreover, $94 \%$ of the participants felt that the learning activities had improved their ability in English. 88\% of the participants considered that the learning activity helped them to increase their knowledge about English.

Meanwhile, $12 \%$ of the participants did not consider it meaningful. In short, students are in a common perception that an e-portfolio is fruitful in improving the students' ability to learn English. This finding corresponds with H. D. Brown \& Abeywickrama (2010) affirming that the portfolio emboldens student-teacher interaction, accommodates self-assessment, proposes peer-assessment and collaboration with peers.

\section{CONCLUSION}

Kind of portfolio allows them to mirror their skills and accomplishment, track their progress, and rehearse practical English skills. Also, Google classroom as an e-portfolio encourages students to do better as well as to embellish their ICT skills. It is considered a valuable tool for students to appraise their learning progress. Besides, it is an effective and beneficial tool to improve learners' ability to learn English. Unfortunately, some problems emerged during the implementation of the eportfolio. Nonetheless, such problems are considered temporal and remediable through sufficient training, teachers' resourcefulness, and a more well-organized procedure. Furthermore, it is fundamental to encourage or motivate students to be more responsible for their learning and become self-regulated learners. Integrating e-portfolio implementation with a student-centred approach is meaningful to revamp their motivation. That is to say, and universities should consider the eportfolio implementation based on students' viewpoints to extend their learning enthusiasm engagement in active learning with e-portfolio. Also, it is necessary to consider strategies designed to promote the concept of learning with an e-portfolio. Though not all educators would directly agree with the idea of using e-portfolio as the assessment tool, there has been a great calling for teachers to integrate technology into teaching-learning activities. At last, it is ineluctable that teachers should embrace such a situation.

\section{REFERENCES}

Akçll, U., \& Arap, İ. (2009). The opinions of education faculty students on learning processes involving e-portfolios. Procedia-Social and Behavioral Sciences, 1(1), 395-400. https://doi.org/10.1016/j.sbspro.2009.01.071

Back, M. D., Stopfer, J. M., Vazire, S., Gaddis, S., Schmukle, S. C., Egloff, B., \& Gosling, S. D. (2010). Facebook profiles reflect actual personality, not self-idealization. Psychological Science, 21(3), 372-374. DOI: 10.1177/0956797609360756

Barrett, H. C. (2007). Researching electronic portfolios and learner engagement: The REFLECT initiative. Journal of Adolescent \& Adult Literacy, 5o(6), 436-449. DOI:10.1598/JAAL.50.6.2

Barrot, J. S. (2014). A macro perspective on key issues in English as second language (ESL) pedagogy in the postmethod era: Confronting challenges through sociocognitive-transformative approach. The Asia-Pacific Education Researcher, 23(3), 435-449. DOI:10.1007/s40299013-0119-4

Barrot, J. S. (2015). A sociocognitive-transformative instructional materials design model for second language (L2) pedagogy in the Asia Pacific: Development and validation. The Asia-Pacific 
Education Researcher, 24(2), 283-297. DOI:10.1007/s40299-014-0179-0

Barrot, J. S. (2016). Using Facebook-based e-portfolio in ESL writing classrooms: impact and challenges. Language, Culture and Curriculum, 29(3), 286-301. https://doi.org/10.1080/07908318.2016.1143481

Baturay, M. H., \& Daloğlu, A. (2010). E-portfolio assessment in an online English language course. Computer Assisted Language Learning, 23(5), 413-428. DOI:10.1080/09588221.2010.520671

Brown, G. T. L., Peterson, E. R., \& Irving, S. E. (2009). Beliefs that make a difference: Adaptive and maladaptive self-regulation in students' conceptions of assessment. International Test Commission Biannual Conference, 2008, Liverpool, United Kingdom; An Earlier Version of This Paper Was Presented at the Aforementioned Conference. https://www.researchgate.net/publication/233871860_Beliefs_that_make_a_difference_ Adaptive_and_maladaptive_self-regulation_in_students'_conceptions_of_assessment

Brown, H. D., \& Abeywickrama, P. (2010). Language assessment: Principles and classroom practices (Vol. 10). Pearson Education White Plains, NY.

Cheng, G. (2008). Implementation challenges of the English language ePortfolio system from various stakeholder perspectives. Journal of Educational Technology Systems, 37(1), 97118. https://doi.org/10.2190/ET.37.1.h

Cheng, G., \& Chau, J. (2013). Exploring the relationship between students' self-regulated learning ability and their ePortfolio achievement. The Internet and Higher Education, 17, 9-15. https://doi.org/10.1016/j.iheduc.2012.09.005

Chye, S. Y., Liau, A. K., \& Liu, W. C. (2013). Student teachers' motivation and perceptions of eportfolio in the context of problem-based learning. The Asia-Pacific Education Researcher, 22(4), 367-375. DOI:10.1007/s40299-012-0022-4

Creswell, J. W., \& Creswell, J. D. (2017). Research design: Qualitative, quantitative, and mixed methods approaches. Sage publications.

Creswell, J. W., \& Poth, C. N. (2016). Qualitative inquiry and research design: Choosing among five approaches. Sage publications.

Genesee, F., \& Upshur, J. A. (1996). Classroom-based evaluation in second language education. Cambridge University Press.

Goldsmith, D. J. (2007). Enhancing learning and assessment through e-portfolios: A collaborative effort in Connecticut. New Directions for Student Services, 2007(119), 31-42. DOI:10.1002/ss.247

Hung, S.-T. A. (2012). A washback study on e-portfolio assessment in an English as a Foreign Language teacher preparation program. Computer Assisted Language Learning, 25(1), 2136. https://doi.org/10.1080/09588221.2010.551756

Iftakhar, S. (2016). Google classroom: what works and how. Journal of Education and Social Sciences, 3(1), 12-18. https://www.jesoc.com/wp-content/uploads/2016/o3/KC3_35.pdf

Janzen, M. (2014). Hot team: Google Classroom. Retrieved from Tlt. Psu. Edu.

Jonassen, D. H. (1991). Objectivism versus constructivism: Do we need a new philosophical paradigm? Educational Technology Research and Development, 39(3), 5-14. https://doi.org/10.1007/BFo2296434

Karami, S., Sadighi, F., Bagheri, M. S., \& Riasati, M. J. (2019). The Impact of Application of Electronic Portfolio on Undergraduate English Majors' Writing Proficiency and Their SelfRegulated Learning. International Journal of Instruction, 12(1), 1319-1334. DOI:10.29333/iji.2019.12184a

Lorenzo, G., \& Ittelson, J. (2005). An overview of e-portfolios. Educause Learning Initiative, 1(1), 1-27. https://library.educause.edu/-/media/files/library/2005/1/eli3001-pdf.pdf

Meyer, E., Abrami, P. C., Wade, C. A., Aslan, O., \& Deault, L. (2010). Improving literacy and metacognition with electronic portfolios: Teaching and learning with ePEARL. Computers \& Education, 55(1), 84-91. DOI:10.1016/j.compedu.2009.12.005

Phellas, C. N., Bloch, A., \& Seale, C. (2011). Structured methods: interviews, questionnaires and observation. Researching Society and Culture, 3, 181-205. https://www.research.manchester.ac.uk/portal/en/publications/structured-methodsinterviews-questionnaires-and-observation(1afdd714-4747-43c6-864f9obo826b2223)/export.html\#export

Stake, R. E. (1995). The art of case study research. sage. 
Thang, S. M., Lee, Y. S., \& Zulkifli, N. F. (2012). The role of the electronic portfolio in enhancing information and communication technology and English language skills: The voices of six Malaysian undergraduates. Computer Assisted Language Learning, 25(3), 277-293. https://doi.org/10.1080/09588221.2012.655299

Weigle, S. C. (2007). Teaching writing teachers about assessment. Journal of Second Language Writing, 16(3), 194-209. https://doi.org/10.1016/j.jslw.2007.07.004

Yastibas, A. E., \& Yastibas, G. C. (2015). The use of e-portfolio-based assessment to develop students' self-regulated learning in English language teaching. Procedia-Social and Behavioral Sciences, 176, 3-13. https://doi.org/10.1016/j.sbspro.2015.01.437

Yin, R. K. (2017). Case study research and applications: Design and methods. Sage publications. 